\title{
Fra Dannevirke til Camp Eden, 700-2003
}

\section{Nikolaj Petersen, Ole Feldbak og Carsten Due-Nielsen}

Ifølge den dominerende teori i international politik er overlevelse udenrigspolitikkens primære mål, og i den forstand har dansk udenrigspolitik haft en forbløffende succesrate siden det første spadestik blev taget til Dannevirke. Redaktørerne af "Dansk Udenrigspolitiks Historie" præsenterer deres konklusioner

Carsten Due-Nielsen, Ole Feldbæk og Nikolaj Petersen, red.: Dansk Udenrigspolitiks Historie, bind 1-6, Gyldendal Leksikon, København 20012005.

Ved afslutningen af Dansk Udenrigspolitiks Historie melder spørgsmålet sig: "Hvad kan vi så lære af det?" Værkets seks bind dækker dansk udenrigspolitik bredt fra Dannevirkes opførelse omkring år 700 til opførelsen af Camp Eden i det sydlige Irak i 2003, to militære anlæg, der i hver sin ende af historien og verden markerer Danmark som internatio- nal aktør. Det virkelig markante er imidlertid, at Danmark i alle de mellemliggende 1300 år har kunnet hævde sig som en permanent medspiller i international politik (bortset fra den kongeløse tid 1332-40 og besættelsen 1940-45). Det er noget, som kun tre-fire af nutidens ca. 200 stater kan matche.

Hvad er så forudsætningen for, at Danmark har kunnet fastholde og udfylde en international rolle over så lang tid? Rollen har nok skiftet over tid, men der har altid været en rolle, stor eller lille, til Danmark: Som stormagt i middelalderens 
nordeuropæiske system, som mellemmagt i 1600-1800-tallets europæiske system, som småstat i europæisk og global politik 1864-1990, og endelig nu en tilstræbt rolle som mellemmagt i efterkoldkrigssystemet, dvs. som en magt, der nok ikke kan øve indflydelse på systemets overordnede struktur, men som " $\mathrm{g} ø \mathrm{r}$ en forskel" inden for denne. Småstatsrollen er altså ikke den historisk givne rolle for Danmark.

\section{De ydre omgivelser}

Rolleskiftene viser afhængigheden af de til enhver tid givne ydre omgivelser med deres magtforhold, trusler og alliancemuligheder. Frem til 1600-tallet bestod den relevante ramme for dansk udenrigspolitik i det nordeuropæiske nærområde omkring Nordsøen og (især) Østersøen, inden for hvilken Danmarks stormagtsrolle blandt andet fandt udtryk i Knud den Stores Nordsøimperium 1014-42, i Valdemarernes Østersørige 1157-1242 og i Kalmarunionen af Danmark, Sverige og Norge fra 1397. Denne tidlige stormagtsrolle var på den ene side betinget af landets overlegne ressourcer i forhold til områdets øvrige enheder, der ikke mindst gav sig udslag i et flådeherredømme i Østersøen, og på den anden side af det tyske kejserriges fragmentering fra 1100-tallet, der neutraliserede en potentielt farlig rival.

I 1600-tallet blev Østersøområdet integreret i et større europæisk system. Det skete, ved at lande som England og Holland fik vigtige økonomiske interesser i området, og $\mathrm{i}$ kraft af, at Tyskland i Trediveårskrigen 1618-48 blev europæisk politiks brændpunkt. I dette spil var Danmark en ikke ubetydelig størrelse, og det var derfor naturligt, at de tyske protestanter søgte at drage Christian 4. (1588-48) ind i deres kamp mod kejseren i Wien. Kongen lod sig lokke og led et overbevisende nederlag. Og efterfølgende måtte han frustreret se til, at Sverige skabte sig den europæiske stormagtsposition, som han selv havde drømt om.

For Danmark blev dette nær skæbnesvangert, for den svenske appetit gik ikke blot på tyske erobringer, men også på indlemmelsen af Danmark. I Karl Gustav-krigene 1657-60 undgik Danmark kun denne skæbne ved hjælp fra de vesteuropæiske magter, der ikke ønskede nogen af de to lande som enehersker over indløbet til Østersøen. Derfor reddede de Danmark fra undergangen, men modsatte sig senere danske forsøg på at genvinde de tabte Skånelande. Først efter år 1700 lykkedes det $\mathrm{i}$ alliance med den nye Østersømagt Rusland at stække Sverige og genskabe en balance i Norden.

International politik hvilede i 1700-tallet på et europæisk stormagtssystem i næsten permanent krigstilstand. Her havde mellemmagten Danmark(-Norge) intet at 
gøre; tværtimod var der gode penge at tjene som neutral søfartsnation. Det blev til den såkaldt "florissante" periode i århundredets anden halvdel. Men med den næsten totale krigsførelse, der kom til at præge Napoleonskrigene omkring år 1800, strammedes betingelserne, og rigets eksistens var nu flere gange alvorligt truet både fra engelsk, fransk, svensk og russisk side. Danmark "slap" med at miste flåden til briterne og Norge til svenskerne, men kom fra 1830'erne på ny i farezonen på grund af nationalitetskampen i Slesvig. "Helstaten" Danmark-Slesvig-Holsten blev her en brik i et trekantspil, hvor Rusland og Storbritannien fungerede som Danmarks "beskyttere" mod de tyske stater.

Men i 1864 gik det galt, da støtten udefra udeblev, og staten mistede en tredjedel af sit territorium. I 1864krigen talte Danmarks ressourcer fortsat noget, ikke mindst flåden, der endnu kunne forsvare øerne mod Preussen og $\varnothing$ strig. Men i stigende grad afhang landets muligheder af stormagternes interesse $i$ at bevare det som en europæisk aktør.

Danmark forvandledes 1864 fra en efterhånden svækket mellemmagt til en decideret småstat uden alliancemuligheder i det nye Tysklands skygge - en situation, der kulminerede i besættelsestidens tab af udenrigspolitisk handlefrihed. De afgørende præmisser for dansk udenrigspolitik i denne periode blev sat af Tysklands nederlag i de to ver- denskrige - nederlag, som Danmark ikke selv bidrog til. Efter Anden Verdenskrig stod Danmark fortsat i skyggen af den dominerende europæiske magt, der nu var Sovjetunionen. Men denne gang var der en alliancemulighed, Atlantpagten, der kunne afbalancere truslen, samtidig med at efterkrigstidens mange-grenede multilaterale samarbejde gav selv mindre stater visse udfoldelsesmuligheder. De afgørende rammer for dansk politik blev fortsat bestemt af Den Kolde Krigs vilkår.

Efter dennes ophør i 1989/90 stod Danmark i den historisk unikke situation at være "fjendeløs" og med mulighed for at føre en aktiv fredsstøttepolitik i Baltikum og på Balkan. I denne periode blev Danmark en mellemmagt, om ikke af navn så af gavn. Og fra 2001 blev Danmark en fast deltager i de amerikanske koalitioner med den typiske mellemmagtsbegrundelse, at "hvis vi vil være en seriøs medspiller, med en reel indflydelse på retningen for den internationale politik, er der i dag intet alternativ til at søge det direkte og åbne samarbejde med USA” (Per Stig Møller 16.9.2004).

Lynturen gennem dansk udenrigspolitiks historie har vist de ydre omgivelsers betydning. Tre forhold har især betydet, at Danmark på en begrænset ressourcebase har kunnet fastholde sin internationale aktørrolle: De europæiske stormagters interesse i at fastholde et selvstændigt Danmark ved indløbet til Østersøen, 
Tysklands interne fragmentering (indtil Bismarck), og Danmarks position som en historisk betydelig flådemagt i kombination med dets karakter af et ørige.

\section{Indre forhold}

Men indre forhold har ligeledes været af betydning. Ekspansionsperioder som Valdemarstiden og Unionstiden var præget af, at kongerne og de stærkeste kræfter i samfundet, adel og kirke, havde fælles interesser, og det samme gjaldt den florissante periode i 2 . halvdel af 1700 -tallet, hvor kongemagten og storborgerskabet slog sig sammen om at udnytte det neutrale flag på verdenshavene. I vor tid har den relative enighed om udenrigspolitikken siden 1990 været en del af baggrunden for, at Danmark har kunnet hæve sig ud af småstatsrollen.

Omvendt er der også mange eksempler på, at interne konflikter har svækket udenrigspolitikken. I århundredet efter Valdemar Sejr (12411340) lagde strid inden for kongeslægten, mellem konge og kirke og mellem konge og adel, grunden til rigets sammenbrud i den kongeløse tid 1332-40. Senere var konflikten mellem Christian 4. og Rigsrådet medvirkende til nederlaget i Trediveårskrigen, og i 1800-tallet førte konflikten mellem dansk og tysk til nederlaget i 1864. Og i nyere tid har indrepolitiske konflikter om Københavns befæstning 1872-94 og sikker- hedspolitikken i 1980'erne svækket handlemulighederne.

\section{Beslutningstagerne}

De ydre og indre omgivelser har dog ikke været enebestemmende for Danmarks internationale rolle, idet de kun sjældent har lukket ethvert handlerum for beslutningstagerne. Når det kommer til stykket, har det afgørende været den politik, som de ansvarlige beslutningstagere, kongen og hans regering, har udstukket. Har politikken været realistisk, dvs. forenelig med de rammer, som ydre og indre forhold sætter? Eller overambitiøs, eventuelt under-ambitiøs?

Historien fremviser eksempler på det hele. Set med overlevelsen som bundlinje har dansk udenrigspolitiks grundkarakter utvivlsomt været realistisk. Landet har trods alt fastholdt sin selvstændige status over en 1300 år lang historie. Der har nok været en pris, idet vigtige landsdele, Skånelandene og det sydlige Slesvig, er skallet af undervejs, men heroverfor står, at det danske rige i størsteparten af sin historie har omfattet mere end sit kerneområde, dvs. været et "imperium". Rigsfællesskabet med Færøerne og Grønland er resterne af dette imperium.

Men der er også eksempler på en forfejlet politik i den forstand, at den har enten overvurderet eller undervurderet de internationale muligheder. Det første har været mest almindeligt. Sammenbruddet 
af Valdemar Sejrs Østersørige i 1220 'erne afslørede, at dette havde hvilet på lerfødder, og Erik Menveds (1286-1319) forsøg på at genoplive det ved en ekspansionspolitik i Nordtyskland var der hverken økonomisk eller politisk grundlag for. Det førte til, at stadig større dele af kongemagtens indtægtsgrundlag blev pantsat, indtil holstenerne $\mathrm{i}$ 1326-40 havde et fuldstændigt panteherredømme i Danmark. I lidt nyere tid var Christian 2.'s forsøg på undertvinge det stadig stærkere Sverige udtryk for en over-ambitiøs politik. Det samme gælder Christian 4.'s forsøg på at slå sig op som tysk protestantisk leder og endnu mere hans søn Frederik 3.'s nær-katastrofale forsøg på revanche over for Sverige i 1657 .

Under enevælden 1660-1848 herskede oftest det gustne overlæg, og territorial politik blev efter Store Nordiske Krig fra 1720 afløst af en profitmaksimerende neutralitetspolitik. I Napoleons-krigene placerede Danmark sig dog af vanvare i Napoleons tabende lejr, fordi man forinden ved at udnytte neutralitetspolitikken til over bristepunktet havde manøvreret sig ind som Englands fjende. Endelig er der grund til delvis at tilskrive nederlaget i 1864 en over-ambitiøs dansk Slesvig-politik, om end det med Bismarcks faste vilje til at ordne spørgsmålet på egne præmisser næppe kunne være gået meget anderledes med en anden dansk politik.
1864 dannede skel i dansk udenrigspolitik. Tvivlen om landets overlevelsesmuligheder i det herskende stormagtssystem bredte sig med den konsekvens, at afkoblingen fra dette blev det udenrigspolitiske hovedmål, klarest formuleret i udenrigsminister P. Munchs (1929-40) "ligge død"-politik. Kernen i debatten om 9. april er, om denne politik var "realistisk" eller, som kritikerne mener, under-ambitiøs? Til fordel for den sidste tolkning taler, at afvisningen af magtpolitik efterhånden var så indgroet, at det ikke blev seriøst overvejet af de ansvarlige, om en anden forsvarspolitik kunne have gjort en forskel.

Besættelsen formåede ikke at udviske den magtskeptiske grundholdning hos hovedparten af politikerne, hvad der kom til at præge dansk udenrigspolitik under Den Kolde Krig. I 1980'erne førte det til striden mellem det alternative flertal og den mere "magtbevidste" udenrigsminister Uffe Ellemann-Jensen. I sidste ende gik ministeren af med sejren og kunne efter 1989 styre dansk udenrigspolitik i retning af en åben brug af militære midler i udenrigspolitikken. Lige så bemærkelsesværdigt var det, at hans efterfølger, den radikale Niels Helveg Petersen, fastholdt linjen i en sådan grad, at Danmark i 1999 blev aktiv deltager i Kosovo-krigen - den første danske krigsdeltagelse siden 1864.

Efter 2001 blev den linje, der byggede på dansk militær magt, endnu 
mere markant med deltagelsen i koalitionskrigene mod Afghanistan og Irak. Danmark har herved genindtaget den rolle som mellemmagt $i$ international politik, som historisk set har været mere "normal" end småstatsrollen. Kun fremtiden vil vise, om den nye udenrigspolitik hører til den realistiske eller overambitiøse kategori.

\section{Historiens lære}

Historiens lære kan lyde banal, men er desuagtet ofte blevet tilsidesat. For det første er de ydre omgivelser af afgørende betydning - både som en begrænsende og muliggørende faktor. Ikke mindst for mindre lande er det afgørende at kunne "læse" omgivelserne korrekt og hverken undervurdere begrænsningerne eller overvurdere mulighederne. I begge tilfælde vil resultatet blive en negativ feedback på den førte politik, der tvinger beslutningstagerne at rebe sejlene.

Det er lige så vigtigt ikke at overvurdere begrænsningerne eller undervurdere mulighederne; problemet er blot, at der i dette tilfælde ikke fremkommer noget retledende feedback. Et land kan derfor føre en suboptimal udenrigspolitik gennem en længere periode, uden at dette behøver at stå klart for beslutningstagerne eller offentligheden. At undgå en underambitiøs udenrigspolitik kræver derfor større statsmandskunst end at undgå den overambitiøse politik.

En anden lære er, at en udenrigspolitik lykkes bedst, når regeringen spiller sammen med de indre omgivelser og er bestræbt på at samle bred opbakning bag sin politik på det parlamentariske plan såvel som i befolkningen som helhed. Også her er der automatiske korrektionsmekanismer i form af kravet om parlamentarisk flertal og i form af parlamentsvalg. Men de er relativt svage, hvor det drejer sig om at sikre et 'bredt' flertal, dvs. mere end det grundlovskrævede simple flertal. Også her er statsmandskunst nødvendig.

Et af bindene i Dansk Udenrigspolitiks Historie, Bo Lidegaards om tiden 1914-45, har titlen Overleveren, men det kunne lige så vel have været titlen på hele værket. Ifølge den dominerende teori i international politik, neo-realismen, er overlevelse udenrigspolitikkens primære mål, og i den forstand har dansk udenrigspolitik haft en forbløffende succesrate som selvstændig aktør i 99 pct. af tiden, siden det første spadestik blev taget til Dannevirke. Det er ikke mindst dette forhold, der har gjort arbejdet med værket så spændende. 